\title{
Erratum to: Communities of practice for supporting health systems change: a missed opportunity
}

\author{
Anita Kothari ${ }^{*}$, Jennifer A. Boyko ${ }^{2}$, James Conklin ${ }^{3}$, Paul Stolee ${ }^{4}$ and Shannon L. Sibbald ${ }^{5}$
}

\section{Erratum}

After publication of the original article [1] it came to the publisher's attention that references 32 and 33 were cited in the incorrect positions in the text. These errors have been corrected in the original article.

- Reference 32 was added to the following sentence, "This CoP exhibited the features of a successful CoP described by others [21, 29, 32]."

- Citations in the sentence, "Some studies have reported on CoPs and their broad impact on systems where CoPs were part of a multi-faceted intervention [32-36]" were changed to, "Some studies have reported on CoPs and their broad impact on systems where CoPs were part of a multi-faceted intervention [34-36]."

\section{Author details}

${ }^{1}$ Western University, School of Health Studies and Schulich Interfaculty Program in Public Health, 1151 Richmond St, London N6A 3 K7, Canada. ${ }^{2}$ Western University, School of Health Studies and Faculty of Information and Media Studies, London, Canada. ${ }^{3}$ Department of Applied Human Sciences and Élisabeth Bruyère Research Institute, Concordia University, Portland, USA. ${ }^{4}$ University of Waterloo, School of Public Health and Health Systems,

Waterloo, Canada. ${ }^{5}$ Western University, School of Health Studies, Schulich Interfaculty Program in Public Health and Department of Family Medicine, London, Canada.

Received: 25 September 2015 Accepted: 25 September 2015 Published online: 05 November 2015

\section{Reference}

1. Kothari A, Boyko JA, Conklin J, Stolee P, Sibbald SL. Communities of practice for supporting health systems change: a missed opportunity. Health Res Policy Syst. 2015;13:33.

\footnotetext{
*Correspondence: akothari@uwo.ca

${ }^{1}$ Western University, School of Health Studies and Schulich Interfaculty Program in Public Health, 1151 Richmond St, London N6A 3 K7, Canada Full list of author information is available at the end of the article

\section{Submit your next manuscript to BioMed Central and take full advantage of:}

- Convenient online submission

- Thorough peer review

- No space constraints or color figure charges

- Immediate publication on acceptance

- Inclusion in PubMed, CAS, Scopus and Google Scholar

- Research which is freely available for redistribution

Submit your manuscript at www.biomedcentral.com/submit 